\title{
"Her Mouth Windfull of Speech": Gender in the English as a Second Language Classroom
}

\section{Kelleen Toohey and Anne Scholefield}

This article explores ways in which gender might be productively investigated in classrooms where students are learning English as a second language. We review studies that posit gender differences in communicative style and review feminist critiques of such studies on the basis of their essentialism and ignoring of political issues. Studies that document differences between the behaviors of boys and girls in classrooms are also examined and critiqued on the same grounds. The point is made that such explorations of difference commonly assume differences to be "normal" or "natural," merely a matter of "style," and ignore relationships of power that might be seen as instantiated in communicative events.

Two projects of the authors are described in which the perceptions of a group of secondary school students of ESL about gendered speech conventions in home, community, and school were investigated. Recognizing that these students (despite diversity in ethnicity) perceive common gender differences in communicative behaviors, the authors speculate about how students might be encouraged to examine the sources of and reasons for these perceptions of difference. The article concludes with a discussion of how linguistic as well as other practices in schools might be examined so as to make that context safer and more positive for girls and ESL students.

In every known culture, men have accused women of being garrulous, of wasting words with lunatic prodigality ... The chattering, ranting, gossiping female, the tattle, the scold, the toothless crone her mouth windfull of speech is older than fairytales. (Steiner, 1975, pp. 41-42)

The talkativeness of women has been gauged in comparison not with men, but with silence. (Spender, 1985, p. 42)

\section{Introduction}

Pennycook (1990) criticizes much previous research in applied linguistics for its treatment of the classroom as a "site of mere linguistic transaction rather than ... as a complex locus of social interaction" (p. 16). He goes on: "Research exploring the social, cultural and political dynamics of second language 
classrooms has been minimal. Fundamental questions, such as the role of gender in classroom interaction and language acquisition, have thus received minimal attention" (p. 16).

Although there is now a fairly large and growing literature that posits, illustrates, and debates the existence of differences in the ways girls and boys behave in school settings generally, Pennycook is right in observing that relatively little specialized work has been done in investigating how sex or gender might be involved in classrooms where English as a second language (ESL) is taught. Porreca (1984), examining sexism in widely used ESL textbooks, found it "remarkable" that since a landmark 1978 study by Hartman and Judd (1978), no other studies had been concerned with ESL textbooks and their portrayal of women. Spencer and Gilbert Lewis pointed out in 1986 that there had been few efforts up to that time with regard to ensuring "sex equity" for students speaking languages other than English. Allwright and Bailey (1991) note, in a review of language classroom research, that research opportunities for investigating gender in language classrooms abound, but they do not cite many studies concerning this topic. With the exception of a few recent articles concerning this topic in the professional literature of second language education (Rockhill, 1991; Doherty, 1992), this area of research has garnered little interest.

This article attempts to take up Pennycook's (1990) challenge to see classrooms as complex loci of social interaction and to contribute to that recent literature that examines gender in ESL classrooms. Because gender studies have not been common in studies of second language learning, we provide a brief outline of issues we see as foundational: sociolinguistic discussions of gender and communication and some feminist responses to this work. In addition, to further situate work on gender in second language classrooms, we provide a review of the large North American literature on gender in classrooms generally. Many of the sociolinguistic investigations and much of the classroom work that investigates "gender differences" in communication are taken here to be problematic in that they tend to ignore both wide variation within gender-specific groups and the political context of gendered talk. Two projects of the authors are described, projects that initially attempted to investigate how a group of ESL students perceived gendered speech conventions in their homes, communities, and classrooms. The article concludes with speculation about future research we might productively undertake to investigate gender, as well as other power constructions, in ESL classrooms.

\section{Ascriptions of Gender Differences in Social Communication}

Although McConnell-Ginet (1988) argues that linguists have historically shown a relative lack of interest in sex or gender ${ }^{1}$ and language, interest, and belief in differences between male and female speech (and sometimes writ- 
ing) have been common, both within and outside North American and Western European academia. Tannen (1990) provides many examples from experience, sociolinguistic studies, and literature to support the argument that differences in the conversational styles of men and women can be demonstrated and are usefully understood as cultural differences. Tannen claims that women in conversation are primarily motivated by needs to negotiate community and intimacy, whereas men are motivated by competitive needs for favorable position in a hierarchy. This hypothesis of intimacy associated with women versus competition associated with men can be found earlier in the work of the feminist moral philosopher Gilligan (1982) and in a great number of studies investigating sex and communication (Kalcik, 1975; Abrahams, 1976; Maltz \& Borker, 1983).

In addition to ascribing intimacy as a characteristic of female speech, women are widely believed to talk more than men, too much and often too loudly about inconsequential matters (Steiner, 1975; Kramerae, 1980). Some sociolinguistic research has demonstrated an empirical distinction with regard to amount between public and private speech: in situations perceived as public, women tend to speak much less than men, whereas in situations perceived as private, women talk more (Eakins \& Eakins, 1978; Swacker, 1976; James \& Drakich, 1989; all cited in Tannen, 1990).

Not all scholars are convinced by the work that investigates "differences" in conversational behaviors of women and men. Many feminist theorists have been concerned about the logic and the effects of speaking of women's experience, ways of knowing, ways of talking, and so on as different from that of men (Fuss, 1989; Butler, 1990). One criticism of these studies has to do with their attribution of particular characteristics to all women. Obviously such studies must ignore differences in the experiences of women across race, class, or sexual orientation lines, for example. Some feminist philosophers have objected to this "evening" of the experience of women, naming this an "essentialist" view. For these theorists, accepting an essentialist view of women denies a multiplicity of experiences and aspirations, which is damaging and limiting (Fraser \& Nicholson, 1988; Haraway, 1985) and which can "promote repressively stereotypic norms of gender-appropriateness" (Bryson \& deCastell, 1993, p. 8).

Another criticism of those studies that conceptualize sexual differences in communication as cultural differences, points out the political construction of particular behaviors. Gal (1991) notes:

Although sociolinguistic studies have long noticed differences between men's and women's everyday linguistic forms, much early research considered talk simply to be an index of identity: merely one of the many behaviors learned through socialization that formed part of men's and women's different social roles. Recent reconceptualizations of gender reject this implicit role theory and promise a deeper understanding of 
the genesis and persistence of gender differences in speech. They argue that gender is better seen as a system of culturally constructed relations of power, produced and reproduced in interaction between and among men and women. (p. 176)

As Gal (1991) points out, documenting and constructing sex differences in communication (or other types of behavior) as cultural may contribute to the belief that differences are simply the product of differential socialization or interests. Seeing women's talk as typically and "naturally" concerned with maintaining intimacy and community may serve to obscure relationships of power and politics, for example. If women are absent from arenas where communication is not concerned with maintaining intimacy, such a view might construe this absence as "normal" and "natural." Seeing the relative public silence of women as cultural, or as "part of being a woman," ignores societal proscriptions against public female talk and the interests that are served by female silence.

There are many different feminist positions on the matters under discussion. In the feminist critiques we have chosen to report here, two major arguments are made about studies documenting differences in male and female verbal behavior. First, the view that men and women's speech behavior can be unproblematically and dualistically differentiated is criticized as ignoring the diversity of experience of men and women across race, culture, and sexual orientation lines. Second, it is argued that when differences are believed to be "cultural" or "natural," one is compelled to ignore the political dimensions of difference: that is, one must ignore whose interests are served by particular differences and how particular behaviors occur in social contexts that are characterized by power differentials.

Some research on gender and schooling has concerned itself with documenting differences in the behaviors of girls and boys. Issues of race, class and other matters are often ignored in this work or, if they become a focus, results become much less clear. Such studies do not investigate how differences might serve particular ends, as particular power relationships are justified or "lived with." We review some of that research below and also describe one study (Eyre, 1991) that has tried to make classroom power relationships explicit.

\section{Gender Differences in Classroom Talk}

Research concerned with gender in the schooling of North American young people has been considerable (Marland, 1983; Brophy, 1985; Sadker \& Sadker, 1986; Gabriel \& Smithson, 1990; Wilkinson \& Marrett, 1985). Since the early 1970s we see a concern in some North American educational literature with establishing whether there are differences in the experiences of boys and girls in classrooms and in some work, a concern with inventing 
strategies to level those differences ("sex equity" initiatives). Many of these studies report that boys demand attention more, call out answers and guess more, and generally participate more actively than girls, creating for themselves (boys) more favorable learning environments (Hillman \& Davenport, 1978; Brophy, Evertson, Anderson, Baum, \& Crawford, 1981; Berk \& Lewis, 1977; Minuchin \& Shapiro, 1983; Sadker \& Sadker, 1982, 1986; Jones, 1989; and others). Boys are also seen to receive more attention, praise, encouragement and criticism from teachers than are girls (Good, Sikes, \& Brophy, 1973; Morse \& Handley, 1985; Maher, 1985; Kramarae \& Treichler, 1990).

Some of the findings of the studies described above have been challenged recently. There are studies showing that girls receive more attention than boys in classrooms (Field, 1980; Grant, 1985) and some showing little difference between the experiences of boys and girls in schools (Eccles \& Blumenfeld, 1985; Leder, 1988). Goodwin $(1990,1992)$ reports a study she conducted with Black American children (admittedly outside a classroom, and she claims the setting to be significant) in which she finds little difference between the verbal behaviors of boys and girls. Girls as well as boys engaged in verbal activities that displayed competition as well as cooperation and concern for community. Grant (1985) observed six desegregated (black and white) grade 1 classrooms and found that race was more important than sex in predicting which children interacted more frequently with teachers. Sex and gender classroom studies have become increasingly more varied in their conclusions, possibly because careful documentation in various settings has pointed out the difficulties with an essentialist viewpoint.

Some current educational research about these matters has been concerned not merely to document differences in the behavior of males and females in classrooms, and to "explain" those differences in terms of "essential characteristics," but rather to attempt to understand how gender and other characteristics of students and teachers (like age, grade, achievement orientations, class, and race of the students and teachers, the subject area of the curriculum, and so on), are involved in the experiences of participants. An ethnographic study completed at one of the secondary schools in which we have worked has been useful in providing background to our projects.

Eyre (1991) describes a group of secondary students taking a coeducational home economics and technical studies class in a multiethnic school in British Columbia that she investigated through participant observation and interviews. Eyre points out the importance of taking into account the complex politics of classrooms and schools such that gender, ethnicity, and other factors are important in characterizing events there. Citing Rich's (1986, p. 74) definition of misogyny: "organized, institutionalized, normalized hostility and violence against women," Eyre sees dominants and subordinates alike (boys and teachers and girls) collaborating in a project of misogyny such that girls are treated as incompetent, subject to verbal and physical 
abuse (seen by most participants as "boys having fun" breaking rules), and silenced in the classroom. To take some examples from her report, with regard to verbal abuse Eyre found: "A particular group of boys frequently called girls 'cows,' 'bitches,' 'witches,' 'whores,' 'dogs,' and 'lesies' and said they were 'evil' and they 'smelled'" (p. 6). Eyre observed as well instances of physical abuse, where girls were hit or poked or shoved by dominant boys. Eyre also found that quieter boys (often, it might appear, boys learning ESL) "also experienced the dominant boys' verbal abuse, silencing, control of space and resources, and physical violence in the classroom" (p. 22).

Eyre's (1991) study points out patterns of power worked out in classrooms such that girls and other subordinates are less powerful than others, notably boys and other dominants. Rather than finding essential characteristics of girls (or subordinates) that leave them vulnerable to abuse, she sees constellations of arrangements that collaborate in making the educational climate for them less positive, indeed less safe, than it is for others. Eyre does not document how often boys talk, or how often girls talk, nor does she tally how many times teachers attend to either group of students. Rather, she tries to examine classroom events that exhibit misogyny, and finds, in addition to gender, other patterns of domination being important in describing meanings in that context. Eyre's study was conducted in one of the schools in which we have been working. The next section of this article describes two ESL classroom projects in which we began by asking students about their experiences of gender and communication.

\section{Two Classroom Projects in Gender and ESL}

Because little work has been done in exploring gender in the experience of ESL students, the focus in these projects was to determine how a group of high school students of ESL see and think about gender conventions in their homes, communities, and "Canadian" classrooms. Although remaining convinced that empirical documentation of differences between male and female speech behaviors in this (or any other setting) would not be useful, we felt it important to investigate initially the gender ideology surrounding speech of the students with whom we were working. Although incomplete, tentative and provocative rather than comprehensive, we believe other researchers and teachers will find the students' observations as interesting as we did.

In the first case, we worked with a class of 20 secondary students of ESL, speaking Cantonese, Tamil, Korean, and Punjabi. The students, ranging in age from 14 to 19 years of age, had been placed in the highest level of ESL instruction at their school. Some of these students were already taking some classes with English-speaking students. After an initial conversation with the students split into two gender-specific groups (10 boys, 10 girls), each student was given a letter in which he or she was asked several questions about 
perceptions about gender and language use; students responded in letters, which were answered. A written dialogue was entered into with the students that continued for a number of exchanges in some instances.

We were interested in how these students perceived matters with regard to male and female speech in their homes, communities, and classrooms. In their letters, the students were asked: "Do you have any sayings in your home language about women's talk or about men's talk? Who talks more: women or men? What do women talk about? What do men talk about?" All students regardless of ethnicity or gender expressed their belief that women talk more than men and that they talk about trivial matters. We quote from several of the letters:

I think that women talk more than men because they like talk about their children, their families, what happened when they went shopping, etc. However, man just talk about their job and business. Men talk about more important things than women. $(\mathrm{AZ}, 1)$

I believe that women talk more than men in my country. On the street, we can always hear women talk loudly. Maybe the men are working in office or they need to busy their work. As in the bus, we can also hear the women's voices, but the men are reading their newspaper. (TL, 1)

There are some saying about the talk of women in my country. Most of the men said that all of the women are trouble because they always phone to their friends and talk about not important things than can be waste time when they are at home. I believe that women talk more than men. The women often talk about many things such as family, children, the price of food, many things not important and men just talk their business. (SF, 1)

Here is one saying about the talk of women in my home language translated into English:

Girl's mouth are like chicken's

I know it is not a very good, polite one, but I can't think of any. Don't mad at me. It just saying that chicken always make lots of noise, so do the girls. (NP, 1)

There really are some sayings about the talk of women in my home language. (When 3 women get together, the place will be looked like a market.) Perhaps I can tell you something about my mom. My mom has quite a few friends. They are mostly women. When they get together, they always talk about dressings and daily life. It is very bustling. (PM, 1)

In our country, guys said that girls' mouth is like chickens mouth because they can't stop talking. And boys are like cats sweet and quiet. 
You can't keep secret to a girl in our country except for old ladys. Teen girls in our country can't keep secret because of their mouth they can't close it. (RR, 1)

We also asked the students who talks more in classes; who does better in mathematics and science classes; what do boys talk about and what do girls talk about; do teachers talk more to boys than to girls? Recognizing that this was a first meeting with the students and that the investigators' research interests were not necessarily of any or much interest to these students, we were intrigued by what they told us. Boys very clearly articulated the belief that girls were quiet in classes, although talkative with their friends in private. They also claimed they had little idea what girls talked to their friends about. Boys said that boys talked about sports, music, and their futures with their friends. Girls, on the other hand, appeared much less united in their beliefs about who talked most in classes, or who was attended to most by teachers. For these girls, issues concerning whether the talk was admonishing or instructional were important (they characterized boys as "fooling around" a lot, especially "Canadian" boys) and they expressed no clear complaints about not being attended to in classes. They did talk about girls being "shyer" than boys and a few discussed at some length the possibility that boys were just smarter than girls, which would explain their (the boys') generally superior performance in mathematics and science classes. A young woman who was identified by her female classmates as especially talented in mathematics and science appeared uncomfortable with their identification. A similar incident involving a talented boy, in the boys' group, seemed to elicit no discernible embarrassment. The opinions expressed by these young people about these matters provided the impetus for the second project.

The second project involved working with a group of 13 secondary ESL students for whom Anne was the teacher. These students ranged in age from 14 to 19 and spoke Vietnamese, Spanish, Korean, and Punjabi. In this class, we conducted several discussions of matters with regard to gender, and students entered into correspondence with Kelleen over the course of about four months. As well, we conducted several individual interviews with the students with regard to gender and language and their schooling experiences generally.

The letters, like those described for the first project, elicited students' beliefs about gender and talk. Like the students in the first project, many but not all of these students believed that women talk more than men, and girls talk more than boys, but not in school. One young woman wrote that she knows that people think women talk more than men, but she's not sure and she thinks that to be sure one "could try some things like vote, ask older people or marking a mark when you hear the men or the women are talking" (CLL, 1.1). One young man wrote: "And if the girls talk alot, I think boys talk 
more. Because boys are more active" (KGL, 2.1). In school, many students perceived that girls are customarily publicly quieter than boys, but some saw this matter of quantity as contingent on other matters. One young woman in the class thought that boys ask for help more in classes when teachers are female and vice versa. Because so many of the teachers in the school (especially those working with students of ESL) are female, this young woman reasoned, boys request and are attended to by teachers more than girls. Students often made the distinction between students of ESL and "Canadian" students. One young woman told me in an interview that Canadian girls as well as boys are noisy:

$\mathrm{K}$ : What about the Canadian girls?

C: Same as Canadian boys, they talk and laugh, sometimes I can't stand it too.

K: Why?

C: Because they're noisy, you know sometimes I have to do my homework and they started to laugh and make noise and I can't pay attention.

$\mathrm{K}$ : Why do you think they are like that?

$\mathrm{C}$ : Maybe because they have a happy life, maybe. (CDI, 1.19)

One young man said that a boy or girl studying ESL has to be quiet because Canadian students "will tell you to be quiet" if you talk too much. Several students reported that students of ESL (boys and girls) are quiet because they're embarrassed about the quality of their English.

Curious about whether students could comment on matters such as those identified by Eyre, we asked some female students if they had experienced harassment at the hands of boys at school. The following excerpt shows that one girl was familiar with this.

K: Some people have said that the boys are kind of rough to the girls you know they push them and they poke them and they sort of threaten them, does this happen to you?

P: We have some boys like (pause) they sometimes go and put their hands in the shirt on my shoulder (pause) and I do avoid it.

K: How do you keep the boys away from you, what do you do to have them stay away?

P: I run away, sometimes I run away and then I tell them to stop.

K: Does that work?

P: Sometimes they get closer to me and try to hug me and I say do not touch me because I do not like it and they stop. (PDI, 1.21)

A common theme with many students was their focused efforts to do well in school, particularly to learn English quickly and well. They reported that they did a lot of studying, that they worked hard in school, and they ap- 
peared impatient with "fooling around," which made it hard for others to "pay attention." Many teachers, of course, observe with approbation what they see as the "task-focus" of secondary ESL students. Many students reported that they see girls asking few questions in class and receiving little help from teachers, but they did not appear to consider this unjust in any way, perhaps because they perceived these girls who get little help to be "shy." We were struck with the extent to which these students saw individuals as solely responsible for their own learning and for "shyness" to be an individual failing. One female student described her personal resolution of the dilemma: "In my culture, girls are supposed to be quiet, but I have to learn English, and I have to ask. I need help, then I have to ask" (CDI, 1.12). Other girls did not express a resolution to this problem, which they readily acknowledged.

Aware that we have only started this investigation, we know that we have a great deal more work to do in terms of trying to understand the ideas and experiences of secondary students of ESL. However, despite the diversity of these students' cultural and linguistic backgrounds, it is clear that many students with whom we had contact believe that women's speech is unimportant, excessive, and often too loud. We are reminded of Spender's (1985) observation that perceptions of the talkativeness of women have to do with proscriptions against female speech. If it is widely believed that women should talk less than men, the implications of this for learning a second language may be quite important. If girls and women are socialized to believe that they usually talk too much, that what they talk about is trivial, and that they should not speak much in public, do they practice less in second language learning classrooms? Do these students really believe that children and family life is unimportant? If personally interested in children and family life, do these individuals consider themselves trivial? Do their convictions of differences in male and female speech serve to justify asymmetrical treatments of boys and girls in classes? Do these beliefs about male and female speech contribute to the misogyny Eyre (1991) observed?

It was our impression that the injustices and contradictions in the lives of these girls, some of which they found clearly apparent, appeared of minor concern to them. Many of these students (boys and girls) have, of course, endured and survived patterns of domination more obviously malignant than those of the Canadian high school. Their previous schooling may have been in schools much less equitable for girls than the schools they now attend. They know that the boys as well as the girls who study ESL are disadvantaged (silenced) in the school, and it may be that the students have some sense that sorting out misogyny and racism does not appear connected with their major concern: learning enough English to get the kind of education they want. 


\section{Conclusion}

Moving from silence into speech is for the oppressed, the colonized, the exploited and those who stand and struggle side by side a gesture of defiance that heals, that makes new life and new growth possible.

(hooks, 1988, p. 9)

Much of the research concerning gender in classrooms has been conducted by adult researchers who document matters like teacher eye gaze, student engagement with teachers by sex, student achievement by sex and subject, and other fairly easily gathered information about classrooms. We are not hopeful that replicating these in ESL classes will be the most fruitful way to proceed in investigating the specific problems of girls and other subordinates in ESL classrooms. Rather, we think that it will be necessary to attempt to understand how classroom participants create meaning in the context of classroom politics.

The secondary school students of ESL with whom we have worked speak quietly about their school experiences. Studious and concerned about their futures, these students are making serious efforts to benefit from the schooling they are receiving. These young people describe themselves as dominated by "Canadian" students, in some areas especially by "Canadian boys." Many of the ethnographic studies we have examined describe arrangements that intersect in making the school environment for girls and other subordinates less safe and less affirming than it is for others (Walden \& Walkerdine, 1986; Eyre, 1991; Thorne \& Luria, 1986). The students with whom we have worked are able to identify some patterns of domination they observe. We hope by exposing these patterns, with the help of the students whose lives are affected by them, that strategies for change will become clearer.

We began to elicit, contradictions and all, the gender ideology of the students with whom we worked. We see a number of logical next steps. We would like to extend this investigation of discourse around gender, by having students, as well as a number of collaborating adults, collect examples of discourse concerning girls, women, and ESL students in the school environment. Learning to analyze these conventions as one is learning English may be helpful. One student outlined a methodology for investigating claims of the loquacity of females. Having students involved in investigating interactions and relationships in the school environment also appears to be important. Using a participatory action research format (McTaggart, 1991), students might be able to explore critically how specific interactions construct relative positions of authority and power in the school. Such research may expose arrangements that students and adults find unacceptable and that they may wish to take on. We hope by examining the customary treatment of girls and ESL students in a secondary school, we have found a 
"codification" (Freire, 1974) that will provide educators and students with strategies for finding what hooks (1988) calls the "gesture of defiance which makes new life and new growth possible."

Note

${ }^{1}$ Much current educational (as well as other) literature confuses sex with gender or takes them to be synonyms. Many feminist theorists have found it useful to distinguish between the biologically given (sex) from the socially constructed (gender). In this context, sex refers to biological and anatomical differences and the relevant categories are female and male (women/men and girls / boys), whereas gender refers to socially constructed categories: feminine and masculine.

\section{Acknowledgments}

A version of this article was presented at the American Association for Applied Linguistics meeting in Seattle in 1992. We thank the students whose ideas have been presented in this article and hope that this presentation does no injustice to their meanings. We thank the editors and anonymous reviewers of the TESL Canada Journal for their helpful comments on previous drafts. Finally, we are grateful to the following people for their various kinds of help: June Beynon, Leigh Castron, Doug Cooper, Suzanne deCastell, Celia Haig-Brown, Shelley Knudsen, and Judy Scott.

\section{The Authors}

Kelleen Toohey teaches at Simon Fraser University. She is interested in minority education and has worked with teachers of ESL, heritage languages and First Nations languages.

Anne Scholefield teaches ESL in Vancouver. She is currently enrolled in a master's degree program investigating the use of the creative arts in the curriculum.

\section{References}

Abrahams, R.D. (1976). Talking black. Rowley, MA: Newbury House.

Allwright, D., \& Bailey, K. (1991). Focus on the language classroom. Cambridge: Cambridge University Press.

Berk, L.E., \& Lewis, N.G. (1977). Sex role and social behavior in four school environments. Elementary School Journal, 77, 205-217.

Brophy, J. (1985). Male and female teacher-student interaction. In L.C. Wilkinson \& C.B. Marrett (Eds.), Gender influences in classroom interaction. New York: Academic Press.

Brophy, J., Evertson, C., Anderson, L., Baum, M., \& Crawford, J. (1981). Student characteristics and teaching. New York: Longman.

Bryson, M., \& de Castell, S. (1993). En/gendering equity: On some paradoxical consequences of institutionalized programs of emancipation. Educational Theory 43, 341-355.

Butler, J. (1990). Gender trouble. New York: Routledge, Chapman and Hall.

Doherty, N. (1992). Challenging systemic sexism in the national language training program. In B. Burnaby \& A. Cumming (Eds.), Sociopolitical aspects of ESL. Toronto: OISE Press.

Eakins, B.W., \& Eakins, R.G. (1978). Sex differences in communication. Boston, MA: Houghton Mifflin.

Eccles, J., \& Blumenfeld, P. (1985). Classroom experiences and student gender: Are there differences and do they matter? In L.C. Wilkinson \& C.B. Marrett (Eds.), Gender influences in classroom interaction. New York: Academic Press.

Eyre, L. (1991). Misogyny in the classroom. Paper presented at the Canadian Women's Studies Association meeting at the Learned Societies Conference, Kingston, ON.

Field, T.M. (1980). Preschool play: Effects of teacher-child ratios and organization of classroom space. Child Study Journal, 10, 191-205. 
Fraser, N., \& Nicholson, L. (1989). Social criticism without philosophy: An encounter between feminism and postmodernism. In L. Nicholson (Ed.), Feminism/postmodernism. New York: Routledge.

Freire, P. (1974). Pedagogy of the oppressed. New York: Seabury Press.

Fuss, D. (1989). Essentially speaking: Feminism, nature and difference. New York: Routledge.

Gabriel, S.L., \& Smithson, I. (Eds.). (1990). Gender in the classroom: Power and pedagogy. Urbana, IL: University of Illinois Press.

Gal, S. (1991). Between speech and silence: The problematics of research on language and gender. In M. di Leonardo (Ed.), Gender at the crossroads of knowledge; Feminist anthropology in the postmodern era. Berkeley, CA: University of California Press.

Gilligan, C. (1982). In a different voice: Psychological theory and women's development. Cambridge, MA: Harvard University Press.

Good, T., Sikes, J.N., \& Brophy, J. (1973). Effects of teacher sex and student sex on classroom interaction. Journal of Educational Psychology, 65, 74-87.

Goodwin, M.H. (1990). He-said-she-said: Talk as social organization among black children. Bloomington, IN: Indiana University Press.

Goodwin, M.H. (1992). Symposium on issues in language and gender: Women talking to women. Paper presented to 1992 meeting of the American Association for Applied Linguistics, Seattle.

Grant, L. (1985). Race-gender status, classroom interaction and children's socialization in elementary school. In L.C. Wilkinson \& C.B. Marrett (Eds.), Gender influences in classroom interaction. New York: Academic Press.

Haraway, D. (1985). A manifesto for cyborgs: Science, technology and social feminism in the 1980s. Socialist Review, 80, 65-107.

Hartman, P., \& Judd, E. (1978). Sexism and TESOL materials. TESOL Quarterly, 12, 383-393.

Hillman, S., \& Davenport, G.Y. (1978). Teacher-student interactions in desegregated schools. Journal of Educational Psychology, 70, 545-553.

hooks, b. (1988). Talking back: Thinking feminist, thinking black. Toronto, ON: Between the Lines.

James, D., \& Drakich, J. (1989). Understanding gender differences in amount of talk. Manuscript, Linguistics Department, University of Toronto, Scarborough Campus.

Jones, M.G. (1989). Gender bias in classroom interactions. Contemporary Education, 60, 218-222.

Kalcik, S. (1975). "... Like Anne's gynecologist or the time I was almost raped": Personal narratives in women's rap groups. Journal of American Folklore, 88, 3-11.

Kramerae, C. (1980). Gender: How she speaks. In E. Ryan \& H. Giles (Eds.), Attitudes toward language variation. London: Edward Arnold.

Kramerae, C., \& Treichler, P. (1990). Power relationships in the classroom. In S.L. Gabriel \& I. Smithson (Eds.), Gender in the classroom: Power and pedagogy. Urbana, IL: University of Illinois Press.

Leder, G. (1988). Do teachers favor high achievers? Gifted Child Quarterly, 32, 315-320.

Maher, F. (1985). Classroom pedagogy and the new scholarship on women. In M. Culley \& C. Portuges (Eds.), Gendered subjects: The dynamics of feminist teaching. London: Routledge and Kegan Paul.

Maltz, D.N., \& Borker, R.A. (1983). A cultural approach to male-female miscommunication. In J. Gumperz (Ed.), Communication, language and social identity. Cambridge: Cambridge University Press.

Marland, M. (Ed.). (1983). Sex differentiation in schooling. London: Heinemann.

McConnell-Ginet, S. (1988). Language and gender. In F.J. Newmeyer (Ed.), Linguistics: The Cambridge survey; IV Language: The sociocultural context. Cambridge: Cambridge University Press.

McTaggart, R. (1991). Principles for participatory action research. Adult Education Quarterly, 41, 168-187. 
Minuchin, P., \& Shapiro, E.K. (1983). The school as a context for social development. In. P. Mussen \& E.M. Heatherington (Eds.), Handbook of child psychology (vol. 4, 4th ed.). New York: Wiley.

Morse, L.W., \& Handley, H.M. (1985). Listening to adolescents: Gender differences in science classroom interaction. In L.C. Wilkinson \& C.B. Marrett (Eds.), Gender influences in classroom interaction. New York: Academic Press.

Pennycook, A. (1990). Towards a critical applied linguistics for the 1990s. Issues in Applied Linguistics 1(1), 8-28.

Porreca, K.L. (1984). Sexism in current ESL textbooks. TESOL Quarterly, 18, 705-724.

Rich, A. (1986). Blood, bread, and poetry: Selected prose 1979-1985. New York: Norton.

Rockhill, K. (1991) Literacy as threat/desire: Longing to be SOMEBODY. TESL Talk 20(1), $89-110$.

Sadker, M., \& Sadker, D. (1982). Sex equity handbook for schools. New York: Longman.

Sadker, M., \& Sadker, D. (1986). Sexism in the classroom: From grade school to graduate school. Phi Delta Kappan, 67, 512-520.

Spencer M.L., Lewis, P.G. (1986). Sex equity in bilingual education, English as a second language and foreign language instruction. Theory into Practice XXV, 257-266.

Spender, D. (1985). For the record: The making and meaning of feminist knowledge. London: Women's Press.

Steiner, G. (1975). After Babel: Aspects of language and translation. New York: Oxford University Press.

Swacker, M. (1976). Women's verbal behavior at learned and professional conferences. In B.L Dubois \& I. Crouch (Eds.), The sociology of the languages of American women. San Antonio, TX: Trinity University.

Tannen, D. (1990). You just don't understand: Women and men in conversation. New York: Morrow.

Thorne, B., \& Luria, Z. (1986). Sexuality and gender in children's daily worlds. Social Problems, 33(3), 176-190.

Walden, R., \& Walkerdine, V. (1986). Characteristics, views and relationships in the classroom. In L. Burton (Ed.), Girls into math can go. London: Holt, Rinehart and Winston.

Wilkinson L.C., \& Marrett, C.B. (Eds.). (1985). Gender influences in classroom interaction. New York: Academic Press. 